\title{
Mosquito population dynamic (diptera: culicidae) in a eutrophised dam
}

\author{
Wermelinger, ED. ${ }^{a}$, Benigno, $C V^{a}$, Machado, RNM. ${ }^{a}$, Cabello, PH. ${ }^{b}$, \\ Meira, AM. ${ }^{a}$, Ferreira. AP. ${ }^{c}$ and Zanuncio, JC. ${ }^{d}$ \\ áLaboratório de Vetores, Departamento de Ciências Biológicas, , Escola Nacional de Saúde Pública Sergio Arouca - ENSP, \\ Fundação Oswaldo Cruz - FIOCRUZ, Rua Leopoldo Bulhões, 1480, Manguinhos, \\ CEP 21041-210, Rio de Janeiro, RJ, Brazil \\ bLaboratório de Genética Humana, Instituto Oswaldo Cruz - IOC, Fundação Oswaldo Cruz -FIOCRUZ, \\ Av. Brasil, 4365, Manguinhos, Rio de Janeiro, RJ, Brazil \\ ${ }^{\mathrm{c}}$ Centro de Estudos da Saúde do Trabalhador e Ecologia Humana - CESTEH, \\ Escola Nacional de Saúde Pública Sergio Arouca - ENSP, Fundação Oswaldo Cruz - FIOCRUZ, \\ Rua Leopoldo Bulhões, 1480, Manguinhos, CEP 21041-210, Rio de Janeiro, RJ, Brazil \\ dDepartamento de Biologia Animal, Universidade Federal de Viçosa - UFV, CEP 36571-000, Viçosa, MG, Brazil \\ *e-mail: edw@fiocruz.br
}

Received July 14, 2011 - Accepted December 6, 2011 - Distributed November 30, 2012

\begin{abstract}
This study observed the mosquito population in a rural eutrophised dam. Larvae of L3 and L4 stages and pupae were dipped out during twelve month collections and the reared to the adult stage for identification. The collections were done along nine metres from the edge of the dam divided in three parts (P1, P2 and P3), each part being $3 \mathrm{~m}$ long. P1 did not have vegetation (grass) along its edge, which would reach or sink into the water to promote some shade on the marginal water. A total of 217 adults of four species was identified with the following constancies and frequencies: Culex quinquefasciatus (Say, 1823) (83\% and 40.6\%), Anopheles (Nyssorhynchus) evansae (Brèthes, 1926) (92\% and 26.7\%), Anopheles (Nyssorhynchus) rangeli (Gabaldon, Cova Garcia and Lopez, 1940) (83\% and $14.3 \%$ ) and Culex nigripalpus (Theobald, 1901) (33\% and 18.4\%). C. quinquefasciatus, A. evansae, A. rangeli and C. nigripalpus were more frequent in the quarters Nov./Dec./Jan. (85.7\%), May/June/July (75\%), Aug./Sept./Oct. (29.4\%) and Aug./Sept./Oct. (23.5\%) particularly in the months of December (88.4\%) Sept.tember (48.94), (38.3) and August (47.62) respectively. The presence of $C$. quinquefasciatus and the high incidence of Daphinia sp. and also the levels of Organic Nitrogen $(0.28 \mathrm{mg} / \mathrm{L})$ and of total Phosphorus $(0.02 \mathrm{mg} / \mathrm{L})$ are indications of the eutrophication of the dam. There was a difference regarding the total of Anopheles (A. avansae + A. rangeli) and Culex species (C. quinquefasciatus $+C$. nigripalpis $)$ between $\mathrm{P} 1$ and $\mathrm{P} 2\left(\chi^{2}=0.0097\right), \mathrm{P} 1$ and $\mathrm{P} 3\left(\chi^{2}=0.0005\right)$, but not between $\mathrm{P} 2$ and P3 $\left(\chi^{2}=0.2045\right)$. The high $C$. quinquefasciatus constancy and frequency were confirmed to be a good biological indicator for a eutrophised environment and A. evansae showed a good potential for this environment. Vegetation can be an important factor for anopheline population dynamic also in eutrophic breeding sites.
\end{abstract}

Keywords: breeding, mosquitoes, eutrophication, Anopheles, Culex.

\section{Dinâmica populacional de mosquitos em açude eutrofizado}

\section{Resumo}

Este estudo observou a dinâmica populacional dos mosquitos em açude eutrofizado na área rural de Paraíba do Sul, Estado do Rio de Janeiro. Foram realizadas 12 coletas mensais de mosquitos imaturos pelo método da conchada em $9 \mathrm{~m}$ de borda, divididos em três postos (P1, P2 e P3), com 3 m de extensão cada. O posto P1 difere por não ter vegetação (capim, mato) na margem, alcançando ou penetrando e promovendo alguma sombra na água. Larvas L3, L4 e pupas foram isoladas para a obtenção dos adultos e identificação. Foram identificados 217 espécimes adultos de quatro espécies, com as seguintes constâncias e frequências: Culex quinquefasciatus (Say, 1823) (83\% e 40,6\%), Anopheles (Nyssorhynchus) evansae (Brèthes, 1926) (92\% e 26,7\%), Anopheles (Nyssorhynchus) rangeli (Gabaldon, Cova Garcia e Lopez, 1940) (83\% e 14,3\%) e Culex nigripalpus (Theobald, 1901) (33\% e 18,4\%), com maiores frequências nos trimestres nov./ dez./jan. (85,7\%), maio/jun./jul. (75\%), ago./set./out. (29,4\%), ago./set./out. (23,5\%) e, nos meses dezembro (88,4\%), setembro $(48,94),(38,3)$ e agosto $(47,62)$, respectivamente. A presença do Culex quinquefasciatus $(40 \%)$ e a elevada incidência de Daphinia sp., juntamente com os níveis de Nitrogênio orgânico ( $0,28 \mathrm{mg} / \mathrm{L})$ e de Fósforo total $(0,02 \mathrm{mg} / \mathrm{L})$, indicam a eutrofização do açude. Houve diferença comparando os totais de anofelinos (A. avansae + A. rangeli) com os totais de culicini (C. quinquefasciatus + C. nigripalpis) entre P1 e P2 $\left(\chi^{2}=0,0097\right)$, e entre P1 para P3 $\left(\chi^{2}=0,0005\right)$, mas não entre P2 e P3 $\left(\chi^{2}=0,2045\right)$. A elevada frequência e a constância de $C$. quinquefasciatus confirmam esta ser uma boa espécie bioindicadora para ambientes eutrofizados e A. evansae apresentou boa potencialidade nesse nível trófico. A vegetação pode influir na dinâmica populacional dos anofelinos também em ambientes eutróficos.

Palavras-chave: criadouros, mosquitos, eutrofização, Anopheles, Culex. 


\section{Introduction}

Due to the importance of mosquitoes to public health, they have been much studied, and that is particularly the case of vector species adapted to anthropic environments. These studies have privileged the adults, mainly females, for epidemiological purpose, to the detriment of studies on their immature aquatic stages. In the meantime, the increasing degradation and pollution of aquatic environments have fostered accelerationof the eutrophication phenomena and pointed to the importance of investigating the mosquito capacity for exploiting the eutrophised breeding sites.

Eutrophication is one of the most important humaninduced modifications affecting aquatic systems in the biosphere (Pinto-Coelho et al., 2005) and it is the enrichment by nutrients, especially nitrogen and phosphorus, leading to the imbalance of the aquatic ecosystem and degeneration of the water quality (Brito de Figueiredo et al., 2007). It may occur in lakes, dams, rivers and even on the marine coast and it may be natural or due to the human activities.

Knowledge of the mosquito capacity to exploit degraded environments is limited to the species which may occur in polluted breeding, such as the Culex quinquefasciatus (Say, 1823), Culex pipiens (Linnaeus, 1758), Culex nigripalpis (Theobald, 1901), Armigeres subalbatus (Coquillett, 1989), (Clements, 1999; Forattini, 2002) and Anopheles (Anopheles) quadrimaculatus (Say, 1824) (Reinert et al., 2003). Before the work presented here, Wermelinger et al. (2010) pointed out the first occurrence of immature stages of species belonging to the subgenus Nyssorhynchus (Blanchard, 1902)- Anopheles (Nyssorhynchus) evansae (Brèthes, 1926) and Anopheles (Nyssorhynchus) rangeli (Gabaldon, Cova Garcia and Lopez, 1940) - in eutrophised breeding habitats. The subgenus Nyssorhynchus includes the main Neotropical vectors of malaria in the genus Anopheles, such as Anopheles darlingi (Root, 1926) and Anopheles aquasalis (Curry, 1932).

There are some reports of Anopheles species that can occur in breeding sites with a lot of organic matter such as A. aquasalis, Anopheles albitarsis (Lynch Arribálzaga, 1878), Anopheles galvaoi (Causey, Deane and Deane, 1943), Anopheles rondoni (Neiva and Pinto, 1922) and Anopheles benarrochi (Gabaldon, Cova Garcia and Lopez, 1941) (Forattini, 1962; Deane et al., 1948; Galvão et al., 1942). Tadei et al. (1998) noticed that localities altered by human activites showed a greater diversity of anopheline species, probably caused by agricultural activities that provide additional nutrients to the area. Usually immature stages of species in the Nyssorhynchus subgenus are found in natural and man-made breeding habitats (Deane et al., 1948; Forattini, 1962, 2002; Faran and Linthicum, 1981; Rubio-Palis, 2000). Former studies were carried out on the biology of Nyssorhynchus group without however measuring trophic levels of breeding habitats. Previous observations were mostly focused on breeding habitat size, type, presence of vegetation, phytoplankton, chlorine and pH levels (Deane et al., 1948; Forattini, 1962, 2002; Faran and Linthicum, 1981; Rubio-Palis, 2000). According to Faran (1980), immatures of Anopheles albimanus (Wiedemann, 1820) are often collected in polluted waters. There are reports of A.rangeli and A.evansae from breeding habitats contaminated with feces (Faran, 1980) and other species of Nyssorhynchus have been reported on breeding habitats rich in organic matter such as A. aquasalis, A. albitarsis, Anopheles strodei (Root, 1926), A. galvaoi, A. rondoni and A. benarrochi (Forattini, 1962; Deane et al., 1948; Faran, 1980; Galvão et al., 1942).Anopheles strodei immature stages were found in water with nitrate concentration varying from $0.008 \%$ to $0.064 \%$ (Faran, 1980). Anopheles tarsimaculatus - perhaps A. aquasalis (Bates, 1970) - larvae were found in breeding habitats in which ammonia nitrogen contents were above 0.3 ppm in Trinidad (Buxton, 1934). Anopheles albimanus (Wiedemann, 1820) immature stages were present in 637.7 ppb of $\mathrm{PO}_{4}$-P in wet season (Reijmákova et al., 1991). Nevertheless, all of those previous reports are inaccurate and insufficient to characterise eutrophised trophic levels. The organic matter had been mostly associated with the visual amount of vegetation. These reports are therefore insufficient to show the potential for the Nyssorhynchus species to explore eutrophicated environments. This is also valid for other subgenus of Anopheles. For example, Anopheles (Celia) minimus (Theobald, 1901) was correlated with low concentrations of nitrogen (De Jesus 1936 apud Bates, 1970) and A. (Anopheles) quadrimaculatus (Say, 1824) was reported in eutrophicated breeding habitats (Reinert et al., 2003).

From those reports, there are no observations on the mosquito population dynamic in eutrophic breeding and these studies may notallow for determining the capacity of the mosquito species to exploit these anthropic and altered environments. In this way, the possible influence of vegetation on this breeding deserves attention because it has been well recorded that vegetation exerts an influence on mosquito populations, especially on Anopheles (Forattini, 1962; Service, 1993). In this work, the mosquito population dynamic was observed in a rural anthropic dam of the city of Paraíba do Sul, Rio de Janeiro state, Brazil.

\section{Material and Methods}

The observations were accomplished in a rural anthropic dam of approximately $560 \mathrm{~m}^{2}$ in the city of Paraíba do Sul, Rio de Janeiro state, Brazil (22 ${ }^{\circ} 13^{\prime} 27.53$ " S and $43^{\circ} 14$ ' 42.73" O), from November 2004 to October 2005. Surrounding or in the dam there are some small herds of animals such as pigs, cattle, ducks and hens and small-scale agriculture cultures for subsistence. A white enamel recipient was used to dip out third and fourth instar larvae and pupae during twelve monthly collections and then reared to the adult stage for identification based on dichotomous keys presented by Consoli and Oliveira (1994) and Forattini (2002). Twelve monthly collections were carried out along nine metres from the edge of the dam divided in three parts (P1, P2 and P3) each one $3 \mathrm{~m}$ long, where $\mathrm{P} 1$ differed from $\mathrm{P} 2$ and $\mathrm{P} 3$ because it did not 
have vegetation (grass) on the edge reaching or sinking into, and promoting some shade on the marginal water. In all collections, three dippings were conducted for each part of the edge. The specimens collected are deposited in the Biological Sciences Department of the National School for Public Health, FIOCRUZ/Rio de Janeiro. After the collections, the levels of Organic Nitrogen and the total Phosphorus of the water were measured. The frequency - percentage of the specimens of the species from the total of specimens collected - and constancy - percentage of the species present from the total of species from the collections - were calculated (Silveira Neto et al., 1976). To observe the possible effects of vegetation on Anopheles and Culicini larvae, Qui Square and Kruskal-Wallis tests were used with the total of adults emerged.

\section{Results}

A total of 241 adults emerged from the immatures (larvae and pupae) collected (Table 1), of which 88 (40.6\%) were C. quinquefasciatus, 58 (26.7\%) were A. evansae, 40 (18.4\%) C. nigripalpus and 31 (14.3\%), $A$. rangeli (Table 2 ). The constancies and frequencies were: C. quinquefasciatus ( $83 \%$ and $40.6 \%)$, A. evansae (92\% and $26.7 \%)$, A. rangeli $(83 \%$ and $14.3 \%)$ and C. nigripalpus (33\% and $18.4 \%$ ). The C. quinquefasciatus, A. evansae, A. rangeli and C. nigripalpus were more frequent in the quarters Nov./Dec./Jan. (85.7\%), May/ June/July (75\%), Aug./Sept./Oct. (29.4\%), Aug./Sept./Oct. $(23.5 \%)$ particularly in the months December $(88.4 \%)$, September (48.94), (38.3) and August (47.6) respectively (Table 2). The levels of Organic Nitrogen and total Phosphorus were $0.28 \mathrm{mg} / \mathrm{L}$ and $0,02 \mathrm{mg} / \mathrm{L}$ respectively. The Kruskal-Wallis test did not reveal differences among P1, P2 and P3 with all species: A. evansae ( $\mathrm{p}=0.4419)$, A. rangeli $(\mathrm{p}=0.3159), C$. quinquefasciatus $(\mathrm{p}=0.8918)$ and $C$. nigripalpis $(\mathrm{p}=0.1600)$. There was a difference with the total of anophelines (A. avansae + A. rangeli) and culicines ( $C$. quinquefasciatus $+C$. nigripalpis) between P1 and P2 $\left(\chi^{2}=6.682 ; \mathrm{p}=0.0097\right), \mathrm{P} 1$ and P3 $\left(\chi^{2}=12.000 ; \mathrm{p}=0.0005\right)$, but not between P2 and P3 $\left(\chi^{2}=1.610 ; \mathrm{p}=0.2045\right)$.

\section{Discussion}

The low diversity of mosquitoes, the high incidence of C. quinquefasciatus and of Daphinia sp. and also the levels of Organic Nitrogen $(0,28 \mathrm{mg} / \mathrm{L})$ and of total Phosphorus $(0.02 \mathrm{mg} / \mathrm{L})$ are indications of the eutrophication of the dam although there are different interpretations for limits of concentration of Phosphorus for each trophic level (Branco, 1986; Esteves, 1998; Tundisi and Matsumura, 1992). Some part of the eutrophication may be due to the small herd of animals such as pigs, cattle, ducks and hens.

Lower levels of $A$. evansae, A. rangeli and C. nigripalpis occurred in the hotter months in opposition to $C$. quinquefasciatus. The highest incidence of $C$. quinquefasciatus in the hotter months was also observed in other studies (Strickman, 1988; Reisen et al., 1992) although these observations were not seen in the tropical season. In São Paulo, Brazil, Laporta et al. (2006) did not detect correlation between climate variation and $C$. quinquefasciatus adults in shelters, although the data for the months of September, February and March were not utilised. This species is well known for it good capacity to exploit polluted breeding and the temperature elevation favoured the time reduction of microorganism generation which may have favoured the rise in the pollution level. This fact may help to explain the high incidence of $C$. quinquefascitaus in the hotter months suggesting that this species may support high levels of pollution in

Table 1. Adults emerged from larvae and pupae collected in a eutrophised dam in Paraiba do Sul city, Rio de Janeiro state, Brazil.

\begin{tabular}{|c|c|c|c|c|c|c|c|c|c|c|c|c|c|c|c|c|c|}
\hline \multirow{2}{*}{ Months } & \multicolumn{4}{|c|}{ A. evansae } & \multicolumn{4}{|c|}{ A. rangeli } & \multicolumn{4}{|c|}{ C. quinquefasciatus } & \multicolumn{4}{|c|}{ C. nigripalpus } & \multirow{2}{*}{ Total } \\
\hline & PI & P2 & P3 & $\sum$ & PI & $\mathbf{P 2}$ & P3 & $\sum$ & PI & $\mathbf{P 2}$ & P3 & $\sum$ & PI & $\mathbf{P 2}$ & P3 & $\sum$ & \\
\hline Nov./04 & 0 & 0 & 2 & 2 & 0 & 1 & 0 & 1 & 7 & 5 & 4 & 16 & 0 & 1 & 0 & 1 & 20 \\
\hline Dec./04 & 1 & 0 & 0 & 1 & 0 & 0 & 0 & 0 & 10 & 3 & 10 & 23 & 1 & 1 & 0 & 2 & 26 \\
\hline Jan./05 & 0 & 0 & 1 & 1 & 0 & 0 & 0 & 0 & 3 & 2 & 4 & 9 & 0 & 0 & 0 & 0 & 10 \\
\hline Feb./05 & 0 & 1 & 0 & 1 & 0 & 0 & 0 & 0 & 1 & 5 & 1 & 7 & 0 & 1 & 3 & 4 & 12 \\
\hline Mar./05 & 0 & 0 & 0 & 0 & 0 & 0 & 0 & 0 & 3 & 0 & 1 & 4 & 0 & 0 & 1 & 1 & 5 \\
\hline Apr./05 & 0 & 0 & 1 & 1 & 0 & 0 & 0 & 0 & 9 & 7 & 1 & 17 & 1 & 0 & 3 & 4 & 22 \\
\hline May./05 & 0 & 2 & 1 & 3 & 0 & 0 & 0 & 0 & 0 & 0 & 0 & 0 & 0 & 0 & 0 & 0 & 3 \\
\hline June/05 & 2 & 0 & 3 & 5 & 0 & 0 & 0 & 0 & 0 & 0 & 1 & 1 & 0 & 2 & 1 & 3 & 9 \\
\hline July/05 & 2 & 4 & 1 & 7 & 0 & 0 & 0 & 0 & 0 & 0 & 0 & 0 & 1 & 0 & 0 & 1 & 8 \\
\hline Aug./05 & 1 & 5 & 6 & 12 & 0 & 1 & 6 & 7 & 0 & 2 & 1 & 3 & 0 & 19 & 1 & 20 & 42 \\
\hline Sept./05 & 2 & 13 & 8 & 23 & 1 & 7 & 10 & 18 & 0 & 1 & 3 & 4 & 0 & 1 & 1 & 2 & 47 \\
\hline Oct./05 & 0 & 2 & 0 & 2 & 0 & 5 & 0 & 5 & 0 & 4 & 0 & 4 & 0 & 2 & 0 & 2 & 13 \\
\hline Total & 8 & 27 & 23 & 58 & 1 & 14 & 16 & 31 & 33 & 29 & 26 & 88 & 3 & 27 & 10 & 40 & 217 \\
\hline
\end{tabular}

P1, P2 and P3 - parts of the edge of dam. 
Table 2. Adults emerged from larvae and pupae collected in a eutrophised dam in Paraiba do Sul city, Rio de Janeiro state, Brazil and its main respective frequencies (f.).

\begin{tabular}{|c|c|c|c|c|c|c|c|c|c|c|c|c|c|c|c|c|c|}
\hline \multirow{2}{*}{ Month } & \multicolumn{4}{|c|}{ A. evansae } & \multicolumn{4}{|c|}{ A. rangeli } & \multicolumn{4}{|c|}{ C. quinquefasciatus } & \multicolumn{4}{|c|}{ C. nigripalpus } & \multirow{2}{*}{ Total } \\
\hline & P1 & $\mathbf{P 2}$ & P3 & $\sum$ & P1 & P2 & P3 & $\sum$ & P1 & P2 & P3 & $\sum$ & P1 & P2 & P3 & $\sum$ & \\
\hline Nov./04 & 0 & 0 & 2 & 2 & 0 & 1 & 0 & 1 & 7 & 5 & 4 & 16 & 0 & 1 & 0 & 1 & 20 \\
\hline Dez./04 & 1 & 0 & 0 & 1 & 0 & 0 & 0 & 0 & 10 & 3 & 10 & 23 & 1 & 1 & 0 & 2 & 26 \\
\hline f. of Dec. & & & & & & & & & & & & 88.4 & & & & & \\
\hline Jan./05 & 0 & 0 & 1 & 1 & 0 & 0 & 0 & 0 & 3 & 2 & 4 & 9 & 0 & 0 & 0 & 0 & 10 \\
\hline Nov.-Jan. & 1 & 0 & 3 & 4 & 0 & 1 & 0 & 1 & 20 & 10 & 18 & 48 & 1 & 2 & 0 & 3 & 56 \\
\hline f. from Nov. to Jan. & & & & 7.1 & & & & 1.8 & & & & 85.7 & & & & 5.4 & \\
\hline Feb./05 & 0 & 1 & 0 & 1 & 0 & 0 & 0 & 0 & 1 & 5 & 1 & 7 & 0 & 1 & 3 & 4 & 12 \\
\hline May/05 & 0 & 0 & 0 & 0 & 0 & 0 & 0 & 0 & 3 & 0 & 1 & 4 & 0 & 0 & 1 & 1 & 5 \\
\hline Apr./05 & 0 & 0 & 1 & 1 & 0 & 0 & 0 & 0 & 9 & 7 & 1 & 17 & 1 & 0 & 3 & 4 & 22 \\
\hline Feb.-Apr. & 0 & 1 & 1 & 2 & 0 & 0 & 0 & 0 & 13 & 12 & 3 & 28 & 1 & 1 & 7 & 9 & 39 \\
\hline f. from Feb. to Apr. & & & & 5.1 & & & & 0 & & & & 71.8 & & & & 23.1 & \\
\hline May/05 & 0 & 2 & 1 & 3 & 0 & 0 & 0 & 0 & 0 & 0 & 0 & 0 & 0 & 0 & 0 & 0 & 3 \\
\hline June/05 & 2 & 0 & 3 & 5 & 0 & 0 & 0 & 0 & 0 & 0 & 1 & 1 & 0 & 2 & 1 & 3 & 9 \\
\hline July/05 & 2 & 4 & 1 & 7 & 0 & 0 & 0 & 0 & 0 & 0 & 0 & 0 & 1 & 0 & 0 & 1 & 8 \\
\hline May-July & 4 & 6 & 4 & 15 & 0 & 0 & 0 & 0 & 0 & 0 & 1 & 1 & 1 & 2 & 1 & 4 & 20 \\
\hline f. from May to July & & & & 75.0 & & & & 0 & & & & 5.0 & & & & 20.0 & \\
\hline Aug./05 & 1 & 5 & 6 & 12 & 0 & 1 & 6 & 7 & 0 & 2 & 1 & 3 & 0 & 19 & 1 & 20 & 42 \\
\hline f. of Aug. & & & & & & & & & & & & & & & & 47.6 & \\
\hline Sept./05 & 2 & 13 & 8 & 23 & 1 & 7 & 10 & 18 & 0 & 1 & 3 & 4 & 0 & 1 & 1 & 2 & 47 \\
\hline f. of Sept. & & & & 48.9 & & & & 38.3 & & & & & & & & & \\
\hline Oct./05 & 0 & 2 & 0 & 2 & 0 & 5 & 0 & 5 & 0 & 4 & 0 & 4 & 0 & 2 & 0 & 2 & 13 \\
\hline Aug.-Oct. & 3 & 20 & 14 & 37 & 1 & 13 & 16 & 30 & 0 & 7 & 4 & 11 & 0 & 22 & 2 & 24 & 102 \\
\hline f. from Aug. to Oct. & & & & 36.3 & & & & 29.4 & & & & 10.8 & & & & 23.5 & \\
\hline Total & 8 & 27 & 23 & 58 & 1 & 14 & 16 & 31 & 33 & 29 & 26 & 88 & 3 & 27 & 10 & 40 & 217 \\
\hline f. Total & & & & 26.7 & & & & 14.3 & & & & 40.6 & & & & 18.4 & \\
\hline
\end{tabular}

P1, P2 and P3 - parts of the edge of dam/f (\%).

this breeding habitat and can be dominant over the other species in these conditions. The high predominance of C. quinquefasciatus in hotter months $(85.7 \%$ in the quarter Nov./Dec./Jan.), together with its high annual constancy $(83 \%)$ and frequency $(40 \%)$, point to this species as a good mosquito bioindicator for eutrophised environments.

Studies on the population dynamics of Nyssohynchus Anopheles are poor, particularly in their breeding sites and there is no data for the species A. evansae and $A$. rangeli. The high constancy (92\%) and good frequency (26.7\%) of A. evansae also points to this species as having good capacity and potential to exploit these environments. A. avansae was more frequent in the cooler months (75\% in May/June/July) and A. rangeli practically only occurred and also was more frequent in the next quarter $(29.4 \%$ in Aug./Sept./Oct.) (Table 2). These results seem to support former observations for A. evansae and A. rangeli in their potential to exploit breeding habitats rich in organic matter (Faran, 1980). Although the Kruskal-Wallis test did not point to a difference among P1, P2 and P3 with all species, the difference with the totals of anopheline and culicini between P1 x P2 $\left(\chi^{2}=0.0097\right)$ and P1 $\times$ P $3\left({ }^{2}=0.0005\right)$ suggests that vegetation can also influence Anopheles population dynamics in eutrophised breeding.

\section{Conclusions}

The $C$. quinquefasciatus constancy and frequency confirm this species as a good mosquito bioindicator for eutrophised environments, with A. evansae showing good potential for that kind of environment. Vegetation can also influence the Anopheles population in those environments being an important factor for anopheline population dynamic in eutrophic breeding sites.

Acknowledgements - To Sandra Conceição Ferreira Monteiro for the English corrections and revision.

\section{References}

BATES, M., 1970. The natural history of mosquitoes. New York: Macmillan Company. 378 p.

BUXTON, PA., 1934. Further studies upon chemical factors affecting the breeding of Anopheles in Trinidad. Bulletin of Entomological Research, vol. 25, p. 491-494. http://dx.doi. org/10.1017/S0007485300012840

BRANCO, SM., 1986. Hidrobiologia Aplicada à Engenharia Sanitária 3. ed. São Paulo: CETESB. 640 p.

BRITO DE FIGUEIREDO, MC., TEIXEIRA, AS., ARAÚJO, LFP., ROSA, MF., PAULINO, WD., MOTA, S. and ARAÚJO, 
C., 2007. Avaliação da vulnerabilidade ambiental de reservatórios à eutrofização. Engenharia Sanitária e Ambiental, vol. 12, no. 4, p. $399-409$.

CLEMENTS, AN., 1999. The Biology of Mosquitoes vol. 2 - Sensory Reception and Behaviour. New York: CABI Publishing. 740 p.

CONSOLI, AGB. and OLIVEIRA, RL., 1994. Principais mosquitos de importância sanitaria no Brasil. Rio de Janeiro: FIOCRUZ. $225 \mathrm{p}$

DEANE, LM., CAUSEY, OR. and DEANE, MP., 1948. Notas sobre a distribuição e a biologia dos anofelinos das regiões Nordestina e Amazônica do Brasil. Revista do Serviço Especial Saúde Pública, vol. 1, p. 1-965.

ESTEVES, FA., 1998. Fundamentos de Liminologia. Rio de Janeiro: Interciência. 602 p.

FARAN, ME., 1980. A revision of the Albimanus Section of the subgenus Nyssorhynchus of Anopheles. Contributions of the American Entomological Institute, vol. 15, p. 1-214.

FARAN, ME. and LINTHICUM, KJ., 1981. A Handbook of the Amazonian Species of Anopheles (Nyssorhynchus) (Diptera: Culicidae). Mosquito Systematics, vol. 13, p. 1-81.

FORATTINI, OP., 1962. Entomologia Médica. São Paulo: Faculdade de Higiene e Saúde Pública. vol. 1, 662 p.

-, 2002. Culicidologia Médica. São Paulo: Edusp. vol. 2, 860 p.

GALVÃO, AL., DAMASCENO, RG. and MARQUES, AP., 1942. Algumas observações sobre a biologia dos anofelinos de importância epidemiológica em Belém do Pará. Arquivos de Hygiene, vol. 12, p. 51-111.

LAPORTA, GZ., URBINATTI, PR. and NATAL, D., 2006. Aspectos Ecológicos de Culex quinquefasciatus Say (Díptera: Culicidae) em abrigos situados no Parque Ecológico do Tietê, São Paulo, SP. Revista Brasileira de Entomologia, vol. 50, p. 125-27.

PINTO-COELHO, RM., BEZERRA-NETO, JF. and MORAIS JUNIOR, CA., 2005. Efeitos da eutrofização sobre o tamanho e a biomassa do zooplâncton crustáceo em um reservatório tropical. Brazilian Journal of Biology, vol. 65, p. 325-338. PMid:16097736.

REIJMÁKOVA, E., SAVAGE, HM., REJMÁNEK, M., ARREDONDO-JIMENEZ, JI. and ROBERTS, RR., 1991. Multivariate analysis of relationships between habitats, environmental factors and occurrence of anopheline mosquito larvae Anopheles albimanus and A. pseudopunctipennis in southern Chiapas, Mexico. Journal of Applied Ecology, vol. 28, p. 827-841. http:// dx.doi.org/10.2307/2404210

REINERT, JF., WHITE, SE. and WILLIS, OR., 2003. Immatures of Anopheles quadrimaculatus collected from atypical habitats. Journal of American Mosquito Control Association, vol. 19, p. 89-90. PMid:12674544.

REISEN, WK., MILBY, MM. and MEYER, RP., 1992. Population Dynamic of Adult Culex Mosquitoes (Diptera: Culicidae) Along the Kern River, Kern County, California, in 1990. Journal of Medical Entomology, vol. 29, p. 531-43. PMid:1625303.

RUBIO-PALIS, Y., 2000. Anopheles (Nyssorhynchus) de Venezuela - Taxonomia, bionomía e importância médica. Caracay: Escuela de Malríología y Saneamiento Ambiental. 118 p.

SERVICE, MW. 1993. Mosquito Ecology. London: Chapman \& Hall. 988 p.

SILVEIRA NETO, S., NAKANO, O., BARDIN, D. and VILLA NOVA, NA., 1976. Manual de Ecologia dos Insetos. Piracicaba: Agronômica Ceres. 419 p.

STRICKMAN, D., 1988. Rate of Oviposition by Culex quinquefasciatus in San Antonio, Texas, During Three Years. Journal of American Mosquito Control Association, vol. 4, p. 339-344. PMid:3199124.

TADEI, WP., THATCHER, BD., SANTOS, JMM., SCARPASSA, VM., RODRIGUES, IB. and RAFAEL, MS., 1998. Ecologic observations on anopheline vectors of malaria in the Brazilian Amazon. American Journal Tropical Medicine and Hygiene, vol. 59, p. 325-335. PMid:9715956.

TUNDISI, JG. and MATSUMURA, T., 1992. Eutrophication of lakes and reservoirs: a comparative analysis, case studies, perspectives. In MARINHO, MC., SANT'ANNA, CL., PAIVA, MTA., TOMITA, N. and PLASTINO, S. (Orgs.). Algae and Environment: a general approach. São Paulo: Sociedade Brasileira de Ficologia. p. 1-33.

WERMELINGER, ED., BENIGNO, CV., MACHADO, RNM., NASCIMENTO TFS., FERREIRA, AP., MEIRA, AM., SOUZA, MB. and ZANUNCIO, JC., 2010. Occurrence of Anopheles (Nyssorhynchus) rangeli (Gabaldon et al) and Anopheles (Nyssorhynchus) evansae (Brethes) (Díptera: Culicidae) in an Eutrophized Dam. Neotropical Entomology, vol. 39. p. 449-450. 
